\title{
Studies on the Biosynthesis of Gholesterol
}

\section{DISTRIBUTION OF ${ }^{14} \mathrm{C}$ IN SQUALENE BIOSYNTHESIZED FROM $\left[M e^{-14} \mathrm{C}\right] A C E T A T E$}

\author{
By J. W. CORNFORTH \\ National Institute for Medical Research, Mill Hill, London \\ AND G. POPJÁK \\ M.R.C. Experimental Radiopathology Research Unit, Hammersmith Hospital, \\ Ducane Road, London, W. 12
}

(Received 31 May 1954)

The hypothesis that squalene takes part in the biosynthesis of cholesterol rests on the evidence of Langdon \& Bloch $(1953 a)$ that squalene is built up from $\left[{ }^{14} \mathrm{C}\right]$ acetate in the liver of the rat and that the $\left[{ }^{14} \mathrm{C}\right]$ squalene thus obtained is converted efficiently into the sterol when fed to mice (Langdon \& Bloch, 1953b; Popják, unpublished; Schwenk, Todd \& Fish, 1954). Further, the distribution of acetate carbons in cholesterol so far established (Wüersch, Huang \& Bloch, 1952; Cornforth, Hunter \& Popják, 1953b; Woodward \& Bloch, 1953; Bloch, 1953) agrees with the assumption that the isoprenoid units, forming the skeleton of squalene, are synthesized from acetate by an overall reaction suggested by Bonner \& Arreguin (1949) for another isoprene polymer, the hydrocarbon of guayule rubber (Scheme 1).

In terms of the notation suggested by Klyne (1954) for the carbon atoms of an isoprenoid unit (cf. Scheme 1), the carbons $w, w^{\prime}$ and $y$ originate from the methyl, and carbons $x$ and $z$ from the carboxyl carbon of acetate. In their explanation of the folding and cyclization of squalene to form the sterol skeleton, Woodward \& Bloch (1953) and Bloch (1953) assumed the correctness of this distribution of acetate carbons among the isoprenoid units. However, there is as yet no experimental proof available.

The biosynthesis of $\left[{ }^{14} \mathrm{C}\right]$ squalene in vitro from $\left[{ }^{14} \mathrm{C}\right]$ acetate by rat liver slices (Popják, 1954) afforded $\left[{ }^{14} \mathrm{C}\right]$ squalene of sufficiently high specific

$$
.2 \mathrm{CH}_{2} \cdot \mathrm{COOH} \longrightarrow \mathrm{CH}_{3} \cdot \mathrm{CO} \cdot \mathrm{CH}_{2} \cdot \mathrm{COOH} \longrightarrow \mathrm{CH}_{3} \cdot \mathrm{CO} \cdot \mathrm{CH}_{3}+\mathrm{CO}_{2}
$$<smiles>CC(=O)CCC(=O)OC(C)(C)C(C(=O)O)C(C)(C)C</smiles>

Scheme 1. Mechanism of formation of an isoprenoid unit from acetate suggested by Bonner \& Arreguin (1949). The notation for the carbon atoms $\left(w, w^{\prime}, x, y, z\right)$ of the isoprenoid units is that put forward by Klyne (1954). activity to enable us to carry out a complete chemical degradation of the hydrocarbon. This report is concerned with the distribution of $\left[{ }^{14} \mathrm{C}\right]$ in squalene formed from $\left[\mathrm{Me}-{ }^{14} \mathrm{C}\right]$ acetate $\left({ }^{14} \mathrm{CH}_{3}\right.$. COONa).

\section{MATERIAL AND METHODS}

[14 C]Squalene. Approximately $100 \mathrm{~g}$. of a mince of the liver of young rats (50-60 g. body weight) were incubated for $5 \mathrm{hr}$. in ten batches in Krebs-Henseleit buffer, pH 7.4 (100 ml./10 g. liver mince) in the presence of $0.3 \%$ glucose and $100 \mu \mathrm{C}(3.1 \mathrm{mg}$.$) of \left[M e-{ }^{14} \mathrm{C}\right]$ sodium acetate in each incubation. The tissue mince was prepared by pressing the liver through the perforated stainless steel end-plate of a syringe. The treatment of the incubation mixture and extraction of $\left[{ }^{14} \mathrm{C}\right]$ squalene was carried out as described before (Popják, 1954). A total of $1 \mathrm{~g}$. of highly purified squalene generously provided by Professor A. Wormall was used as carrier. The $\left[{ }^{14} \mathrm{C}\right]$ squalene, separated from $\left[{ }^{14} \mathrm{C}\right]-$ cholesterol by chromatography (Langdon \& Bloch, 1953a) on alumina washed with methyl formate, was further purified from contaminating $\left[{ }^{14} \mathrm{C}\right]$ cholesterol by the addition of $\mathbf{0 . 5} \mathrm{g}$. of unlabelled cholesterol followed by chromatography on alumina. This 'washing out' process was repeated 3 times, after which the cholesterol eluted from the column was devoid of detectable radioactivity. The squalene was chromatographed once more without added cholesterol. It should be mentioned that the cholesterol eluted from the column after the first 'washing out' contained significant radioactivity. The [ $\left.{ }^{14} \mathrm{C}\right]$ squalene was kept sealed under $\mathrm{N}_{2}$ at $+5^{\circ}$ until required. The specific activity of the squalene assayed on the hexahydrochloride in infinitely thick samples and on squalene itself in thin samples agreed within the counting error of the assay ( $\pm 2 \%$ ).

\section{Degradation of squalene}

Oxidative ozonolysis was used as the first step essentially as described by Strain (1933) for the ozonolysis of lycopene. Oxidative ozonolysis of 1 mole of squalene (cf. Heilbron, Owens \& Simpson, 1929) should give rise theoretically to 2 moles of acetone, 4 moles of laevulinic (4-oxopentanoic) acid and 1 mole of succinic acid (Scheme 2). By the process described below these three degradation products were obtained in $55 \%, 70-75 \%$ and $30-50 \%$ yields of the theoretical respectively.It is seen from $S$ cheme 2 that the carboxyl 
carbons of succinic acid are derived from carbon atoms $y 3-y 3^{\prime}$ and the methylene carbons from $z 3-z 3^{\prime}$. Also, in each molecule of laevulinic acid each carbon atom is obtained from analogous positions of the isoprenoid units, i.e. from carbons $y, z, w, x$ and $w^{\prime}$ (in order starting from carboxyl), carbon atoms $x 2, x 2^{\prime}, x 3$ and $x 3^{\prime}$ furnishing the carbonyl and carbons $y 1, y 1^{\prime}, y 2$ and $y 2^{\prime}$ the carboxyl carbon. Thus the carbon-by-carbon degradation of laevulinic acid alone should give an unequivocal answer as to the distribution of acetate carbons in squalene.

Squalene (400 mg.) in $10 \mathrm{ml}$. of light petroleum (b.p. $60-80^{\circ}$ ) was ozonized at $0^{\circ}$ with a 5-7\% stream of ozone in $\mathrm{O}_{2}$ for $2 \mathrm{hr}$., then $2 \mathrm{ml}$. of acetic acid were added and the ozonization was continued for another $2 \mathrm{hr}$., by which time all the light petroleum was blown off and the acetic acid froze. To the crystal-clear thawed solution of ozonide $0.5 \mathrm{ml}$. of $\mathrm{H}_{2} \mathrm{O}_{2}$ (' 100 vol.', British Drug Houses Microanalytical Reagent) was added and the mixture shaken for $1 \mathrm{hr}$. at room temperature, when a further $0.5 \mathrm{ml}$. of $\mathrm{H}_{2} \mathrm{O}_{2}$ was added. After another $1 \mathrm{hr}$. at room temperature $3 \mathrm{ml}$. of water and $2 \mathrm{ml}$. of $\mathrm{H}_{2} \mathrm{O}_{2}$ were added and the reaction mixture was heated at $70^{\circ}$ under a reflux condenser for $3 \mathrm{hr}$, by which time only a faint cloudiness was produced on addition of $5 \mathrm{ml}$. of water. The reaction mixture was brought to pH 5 with $\mathrm{NaOH}$, then the acetone was distilled over into water with a stream of $\mathrm{N}_{2}$.

Acetone. The distillate was treated further for the purification and degradation of acetone as described previously (Popják, French, Hunter \& Martin, 1951). From a small sample of the purified acetone in water the 2:4-dinitrophenylhydrazone was prepared for radioactive counting.
Separation of acidic products. The original reaction mixture, from which the acetone was distilled, was made strongly acid by the addition of $10 \mathrm{ml}$. of $2 \mathrm{~N}-\mathrm{H}_{2} \mathrm{SO}_{4}$ and the acetic acid and $\mathrm{H}_{2} \mathrm{O}_{2}$ were removed by steam distillation. There were only traces of ketonic material in the steam distillate which was discarded. The residue of steam distillation was extracted 10 times with an equal volume of ether; the extracts were combined, dried over anhydrous $\mathrm{Na}_{2} \mathrm{SO}_{4}$, filtered and distilled to dryness. The dry residue was extracted with $\mathrm{CHCl}_{3}$, leaving behind crystalline succinic acid which was recrystallized from a little water. The $\mathrm{CHCl}_{3}$ solution was evaporated to dryness and the residue extracted with water which dissolved the laevulinic acid, leaving behind some peroxides insoluble in water. A portion of the aqueous solution was used for isolation of the 2:4dinitrophenylhydrazone of laevulinic acid for radioactive counting (m.p. 199-201 ${ }^{\circ}$; an authentic sample gave m.p. $199-201^{\circ}$; mixed m.p. $200-201^{\circ}$ ) and from the remainder the phenylhydrazone of laevulinic acid was prepared after the addition of carrier laevulinic acid phenylhydrazone for further degradation as described below.

Degradation of succinic acid. This was done by the Curtius (1895) rearrangement of succinic acid to the diurethane (Scheme 3, cf. Calvin, Heidelberger, Reid, Tolbert \& Yankwich, 1949). We are indebted to Mr V. H. T. James, of the National Institute for Medical Research, for details of an improved procedure for the Curtius rearrangement. Methyl succinate, obtained by the treatment of succinic acid (85 mg. obtained from squalene $+153 \mathrm{mg}$. inactive acid) with an excess of diazomethane was converted quantitatively into the dihydrazide by treating the ester in ethanol

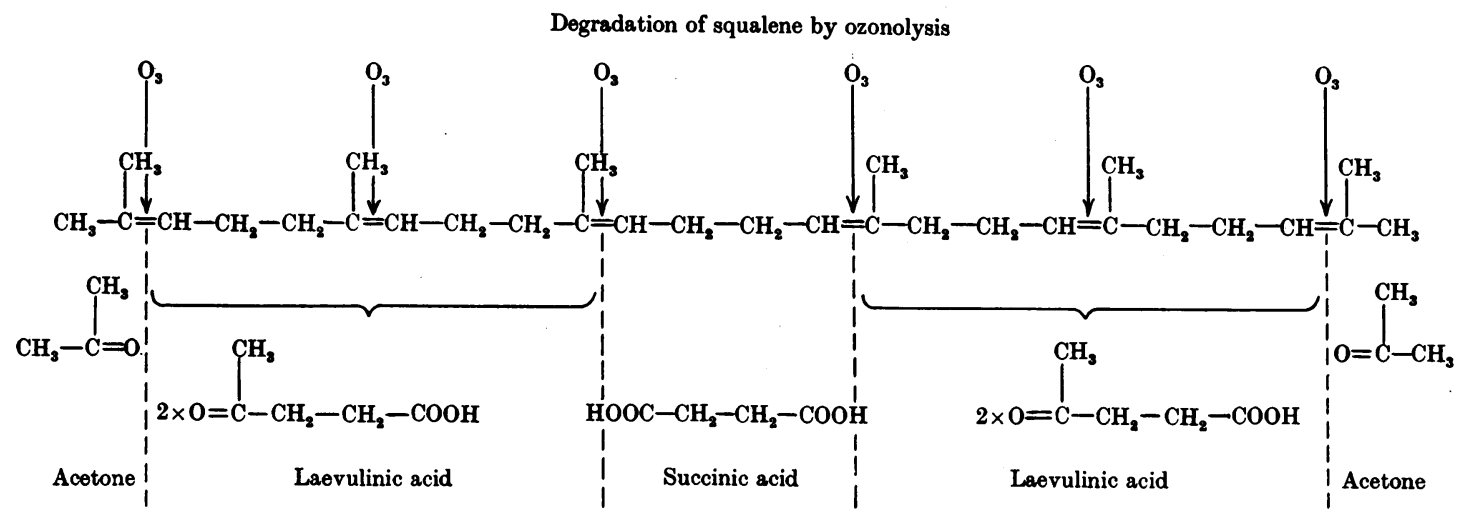

Scheme 2. Degradation of squalene by oxidative ozonolysis.

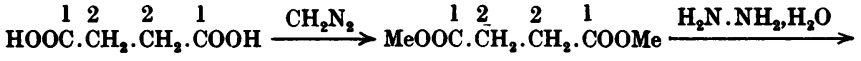

$$
\begin{aligned}
& \rightarrow \mathrm{H}_{2} \mathrm{~N} \cdot \mathrm{NH} \cdot \mathrm{OC} \cdot \mathrm{CH}_{2} \cdot \mathrm{CH}_{2} \cdot \mathrm{CONH} \cdot \mathrm{NH}_{2} \stackrel{\mathrm{NaNO}_{2}}{\longrightarrow} \mathrm{N}_{3} \mathrm{OCl} \cdot \mathrm{CH}_{2} \cdot \mathrm{CH}_{2} \cdot \mathrm{CON}_{3} \longrightarrow \\
& \stackrel{\mathrm{EtOH}}{\longrightarrow} \mathrm{Et} . \mathrm{OOC} \cdot \mathrm{NH} \cdot \stackrel{2}{\mathrm{CH}_{2}} \stackrel{2}{\mathrm{CH}_{2}} . \mathrm{NH} \cdot \mathrm{COO} \cdot \mathrm{Et} \stackrel{\mathrm{HBr}}{120^{\circ}} \\
& \longrightarrow \stackrel{2}{2} \stackrel{2}{2} \cdot \stackrel{1}{\mathrm{HBr}, \mathrm{H}_{2} \mathrm{~N}} \cdot \stackrel{\mathrm{CH}}{\mathrm{CH}_{2}} \cdot \mathrm{NH}_{2}, \mathrm{HBr}+2 \mathrm{CO}_{2}+2 \mathrm{EtOH}
\end{aligned}
$$

Scheme 3. Degradation of succinic acid by the Curtius (1895) rearrangement. 
with hydrazine hydrate. The dihydrazide of succinic acid was recrystallized from water with ethanol. The dihydrazide $(2 \mathrm{~m}$-moles) was dissolved in water $(2.5 \mathrm{ml}$.) and $0.7 \mathrm{ml}$. of $6 \mathrm{~N}-\mathrm{HCl}$ was added. This solution was covered with ether (5 ml.) and cooled in an ice bath. With good mechanical stirring, a solution of sodium nitrite (4.1 m-moles in $2 \mathrm{ml}$. water), also cooled, was added instantaneously. After a few seconds of vigorous stirring the reaction mixture was transferred to a separating funnel and extracted quickly with two further $5 \mathrm{ml}$. portions of ether. The rapid extraction with ether after the addition of $\mathrm{NaNO}_{2}$ is essential for good yield of urethane in the next step.

The combined ether extracts were dried over fused $\mathrm{CaCl}_{2}$ for $15 \mathrm{~min}$. and decanted into a small flask. The drying agent was washed with a little more ether and the washings were added to the bulk of the solvent. Ethanol $(10 \mathrm{ml}$.) was added and the ether removed by distillation through a short fractionating column. The residual ethanolic solution was refluxed for $1 \mathrm{hr}$. and then evaporated to dryness under reduced pressure. This left a very faintly brownish oil which solidified into a mass of crystals on cooling. Yield of crude urethane was $90 \%$. The crude ethylenediamine diurethane was purified by crystallization from a little water (m.p. $111^{\circ}$, reported $112^{\circ}$ ).

The urethane (75 mg.) was heated for $90 \mathrm{~min}$. with $1 \mathrm{ml}$. of constant-boiling $\mathrm{HBr}\left(120^{\circ}\right)$ under a reflux condenser with a small stream of $\mathrm{N}_{2}$ passing through the system; the evolved $\mathrm{CO}_{2}$, derived originally from the carboxyl carbons of succinic acid, was collected as $\mathrm{BaCO}_{3}(140 \mathrm{mg}$.). The excess $\mathrm{HBr}$ was distilled off from the reaction mixture under reduced pressure. The crude ethylenediamine dihydrobromide was dissolved in $1 \mathrm{ml}$. of water, the solution was centrifuged to remove a little insoluble material and then concentrated to about $0.2 \mathrm{ml}$. on a hot water bath and, while still hot, $5 \mathrm{ml}$. of hot methanol were added. The dihydrobromide started to crystallize almost immediately; it was purified by one further crystallization from water and methanol and was plated directly for assay of ${ }^{14} \mathrm{C}$. Yield of the recrystallized ethylenediamine dihydrobromide was $60 \mathrm{mg}$. (from $75 \mathrm{mg}$. of urethane).

Degradation of laevulinic acid. This was carried out by reactions analogous to those employed previously for the degradation of 2-methylcyclohexanone (Cornforth, Hunter \& Popják, 1953a) (see Scheme 4). The phenylhydrazone of laevulinic acid was reduced to 4-aminopentanoic acid ( $\gamma$ aminovaleric acid) with aluminium amalgam. Methylation of the amino acid with methyl iodide gave the betaine, which when fused with $\mathrm{KOH}$ at $350^{\circ}$ for 10 min. gave in an almost quantitative yield acetic acid (from the carboxyl and $\alpha$-carbons) and propionic acid (from the $\beta$-, $\gamma$ - and $\delta$-carbons) in complete analogy with the reactions described for the betaine prepared from 6 -aminoheptanoic acid (Cornforth et al. $1953 a)$.

An aqueous solution containing $100 \mathrm{mg}$. of [ $\left.{ }^{14} \mathrm{C}\right]$ laevulinic acid was concentrated at low pressure to about $2 \mathrm{ml}$. A solution of phenylhydrazine $(0.1 \mathrm{ml}$.) in acetic acid $(0.3 \mathrm{ml}$.) was added gradually. Recrystallized, non-radioactive laevulinic acid phenylhydrazone (535 mg.) was stirred in and the total product was collected and washed with water. The phenylhydrazone was now reduced essentially by the procedure of Fischer \& Groh (1911): it was dissolved in $80 \%(\mathrm{v} / \mathrm{v})$ ethanol $(10 \mathrm{ml}$.) and treated with amalgamated aluminium (from $0.5 \mathrm{~g}$. $\mathrm{Al}$ ). The mixture was shaken for $1 \mathrm{hr}$, then occasionally during $2 \mathrm{hr}$, left overnight, and then filtered, the residue being well washed with water. The filtrate was evaporated at low pressure; the residue was washed with ether and treated with ethanol. The white crystalline 4-aminopentanoic acid (264 mg.) was collected. Of this, $239 \mathrm{mg}$. were added to a suspension of $\mathrm{Ag}_{2} \mathrm{O}$ (from $1.7 \mathrm{~g} . \mathrm{AgNO}_{3}$ ) in methanol $(6 \mathrm{ml}$.). After a few minutes' swirling, methyl iodide $(0.62 \mathrm{ml}$.) was added and the mixture was shaken for $21 \mathrm{hr}$. The silver precipitate was removed and washed well with methanol; the filtrate was evaporated at low pressure. The residue was dried in vacuo over $\mathrm{P}_{2} \mathrm{O}_{5}$, dissolved in a little isopropanol and treated gradually with dry ether as crystallization proceeded. The hygroscopic, solvated crystals of 4-aminopentanoic acid methylbetaine (65 mg.) were collected (a non-radioactive sample had m.p. about $200^{\circ}$ (decomp.) after drying; found on dried material: $\mathrm{N}, 8 \cdot 3 . \mathrm{C}_{8} \mathrm{H}_{17} \mathrm{O}_{2} \mathrm{~N}$ requires $\mathrm{N}, 8 \cdot 8 \%$ ). This betaine was heated with $\mathrm{KOH}\left(1 \cdot 2\right.$ g.) at $350-360^{\circ}$ for $10 \mathrm{~min}$. The products of the fusion of the betaine with $\mathrm{KOH}$, propionic and acetic acid were separated from one another by chromatography and degraded further as described previously (Cornforth et al. 1953b). On account of the unexpectedly low yield of the betaine in the experiment with the labelled material, it was necessary to dilute about threefold the propionic and acetic acids after chromatography with inactive acids for further degradation. Even after such dilution the standard error of the radioactive counts did not exceed $\pm 5 \%$ for the more active carbons, and $\pm 10 \%$ for the carbons of lesser activity.

Assay of ${ }^{14} \mathrm{C}$. All radioactive counts were taken on solid samples with an end-window counter as described previously (Popják, 1950) and were corrected by the appropriate factors for the various dilutions with inactive materials.

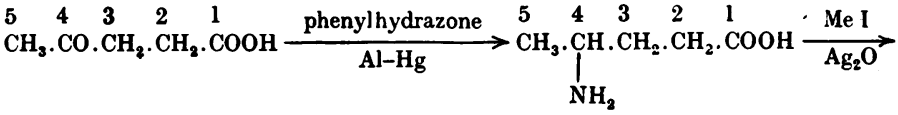

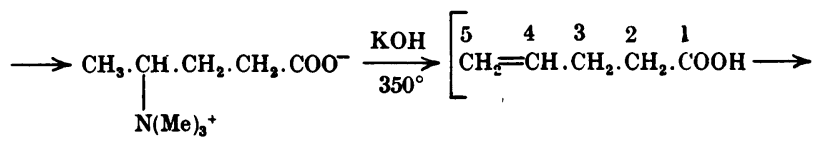

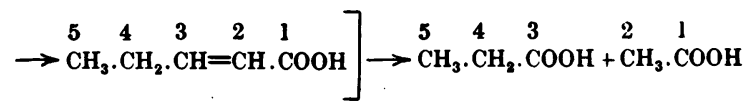

Scheme 4. Degradation of laevulinic acid. 


\section{RESULTS AND DISCUSSION}

The results shown in Table 1 demonstrate that $\left[{ }^{14} \mathrm{C}\right]$ from $\left[\mathrm{Me}-{ }^{14} \mathrm{C}\right]$ acetate is distributed along the whole skeleton of squalene and hence the biosynthesis of the whole molecule can be inferred. In detail it can be seen that carbons $w, w^{\prime}$ and $y$ of the isoprenoid units are derived from the methylcarbon of acetate to an equal extent, since the specific activities of these carbon atoms sampled from different parts of the molecule were equal within experimental error. The slight but definite labelling of carbons $x$ and $z$ may be attributed to the formation of carboxyl-labelled acetate from $\left[\mathrm{Me}^{-{ }^{14} \mathrm{C}}\right]$ acetate via the citric acid cycle before the formation of the isoprenoid units. A similar shift in the labelling of acetate carbons was found previously in cholesterol formed from $\left[\mathrm{Me}^{\left.-{ }^{14} \mathrm{C}\right] \text { acetate (Cornforth }}\right.$ et al. $1953 b$ ).

Although our results are in harmony with the distribution of acetate carbons in the isoprenoid units as postulated by Bonner \& Arreguin (1949), nevertheless, alternative reaction mechanisms may exist which would give similar results. In particular these authors assumed the decarboxylation of acetoacetic acid before its condensation with another molecule of acetate (cf. Scheme 1).
It is now known that the 'active' form of acetate is acetyl-coenzyme A (Lynen, Reichert \& Rueff, 1951) and that the acetoacetic acid formed from the condensation of 2 molecules of active acetate appears also as a coenzyme $A$ derivative (Lynen, Wessely, Wieland \& Rueff, 1952; Stern, Coon \& del Campillo, 1953; Beinert, 1953). It does not seem improbable that the biosynthesis of isoprenoid units proceeds by the reaction of acetoacetyl-CoA with acetyl-CoA, particularly since Brady \& Gurin (1951) demonstrated the utilization of acetoacetate for cholesterol synthesis by liver slices. The recent observations by Klein \& Lipmann $(1953 a, b)$ and by Boyd (1953) also suggest a dependence of biosynthesis of ergosterol and of cholesterol on the coenzyme A content of cells. According to some unpublished experiments of Langdon, quoted by Bloch (1954), unlabelled $\beta$-hydroxy- $\beta$-methylglutaric acid, when added to rat liver 'homogenates' (cf. Bucher, 1953), depressed the incorporation of ${ }^{14} \mathrm{C}$ from $\left[{ }^{14} \mathrm{C}\right]$ acetate into cholesterol. This observation could be interpreted to indicate the utilization of this dicarboxylic acid for the formation of isoprenoid units and of cholesterol and hence causing a 'dilution' of the labelled intermediates formed from $\left[{ }^{14} \mathrm{C}\right]$ acetate. Bloch (1954) suggests that $\beta$-hydroxy- $\beta$-methylglutaric acid may arise by the

Table 1. Specific activity of the carbons of $\left[{ }^{14} \mathrm{C}\right]$ squalene biosynthesized from $\left[M e^{-14} \mathrm{C}\right]$ acetate

$\begin{array}{lc}\text { Carbon atoms of squalene } & \\ \text { isoprenoid units* } & \text { Counts/min./mg. C } \\ \text { All } & 2160 \\ \left(w, x, w^{\prime}\right)-\left(1,1^{\prime}\right) & 2480 \\ \left(w, w^{\prime}\right)-\left(1,1^{\prime}\right) & 3560 \\ (x)-\left(1,1^{\prime}\right) & 340 \\ (y, z)-\left(3,3^{\prime}\right) & 1758 \\ (y)-\left(3,3^{\prime}\right) & 3400 \\ (z)-\left(3,3^{\prime}\right) & 368 \\ \left(w^{\prime}, x, w\right)-\left(2,3,2^{\prime}, 3^{\prime}\right)- & 2260 \\ (z, y)-\left(1,2,1^{\prime}, 2^{\prime}\right) & \\ \left(w^{\prime}, x, w\right)-\left(2,3,2^{\prime}, 3^{\prime}\right)- & 2260 \\ (z, y)-\left(1,2,1^{\prime}, 2^{\prime}\right) & \\ (y)-\left(1,2,1^{\prime}, 2^{\prime}\right) & 3660 \\ (z)-\left(1,2,1^{\prime}, 2^{\prime}\right) & 224 \\ (w)-\left(2,3,2^{\prime}, 3^{\prime}\right) & 3605 \\ (x)-\left(2,3,2^{\prime}, 3^{\prime}\right) & 234 \\ \left(w^{\prime}\right)-\left(2,3,2^{\prime}, 3^{\prime}\right) & 3520\end{array}$

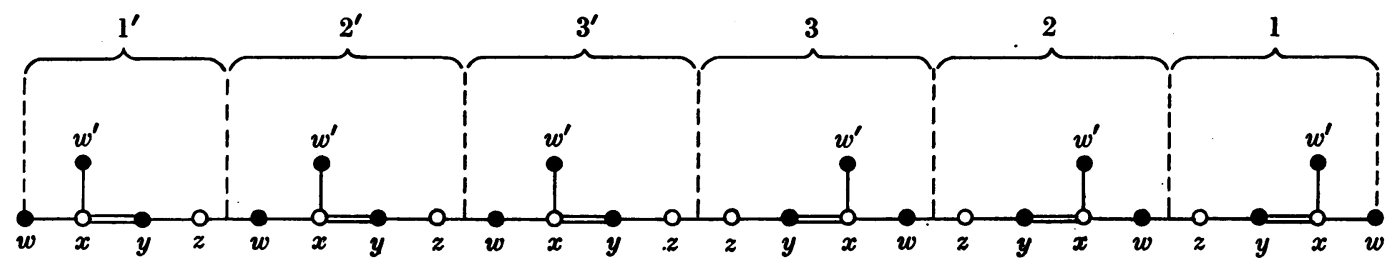

* The notation of Klyne (1954) has been adopted to denote the carbon atoms of the isoprenoid units; the key to this notation is given by the schematic formula of squalene at the bottom of the table. The letters $\left(w, w^{\prime}, x, y, z\right)$ in col. 2 denote the carbon atoms in the isoprenoid unit, and the numerals the numbering of such units from which the particular carbon atoms were derived.

The full circles in the formula indicate carbon atoms derived from the methyl carbon of acetate. 
condensation of one mole of acetoacetate with one mole of acetate and that its decarboxylation would yield a branched five-carbon compound. This reaction might be looked upon as analogous to the formation of citrate from oxaloacetate and acetate. It is of interest to note that $\beta$-hydroxy- $\beta$-methylglutaric acid could give $\beta \beta$-dimethylacrylic acid by a dehydration-decarboxylation reaction in which the Ogston (1948) effect might operate to secure the elimination of a particular carboxyl-group-either that originating from acetoacetic acid or that derived from the third acetic acid molecule (Scheme 5). It is seen that if the biosynthetic process is being studied with $\left[{ }^{14} \mathrm{C}\right]$-labelled acetic acid, the distribution of $\left[{ }^{14} \mathrm{C}\right]$ in the isoprenoid units formed by either of the above mechanisms would be the same. Likewise the evidence available does not determine whether the superfluous carboxyl is eliminated before or after the condensation of successive isoprenoid units.

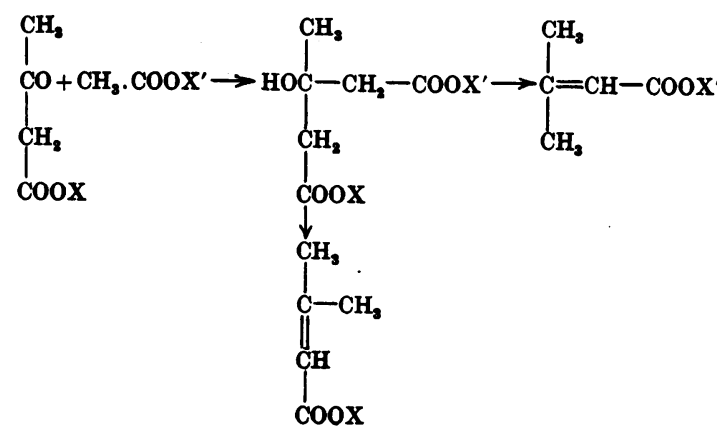

Scheme 5. Possible mechanisms for the formation of isoprenoid units from acetoacetic and acetic acids.

Although the inference from in vitro experiments reported recently was that squalene itself is not an obligatory intermediate in the biosynthesis of cholesterol (Popják, 1954), it appears to us that the formation of this hydrocarbon might serve conveniently as a model for the study of some parts of the more difficult problem of the biosynthesis of cholesterol, since the distribution of isotopic carbon in squalene may be examined much more easily than in the sterol.

\section{SUMMARY}

1. $\left[{ }^{14} \mathrm{C}\right]$ Squalene biosynthesized from $\left[M e-{ }^{14} \mathrm{C}\right]$ acetate by liver mince was degraded by oxidative ozonolysis to acetone, succinic acid and laevulinic acid. The carbon-by-carbon degradation of these three fragments was completed.

2. The results showed that the entire carbon skeleton of squalene was formed from acetate and that carbons $w, w^{\prime}$ and $y$ (according to the notation of
Klyne, 1954) of the isoprenoid units are derived from the methyl carbon of acetate. By inference it is suggested that carbons $x$ and $z$ originate from the carboxyl-carbon of acetate.

3. Possible mechanisms for the formation of isoprenoid units from acetate and the relationship between the biosynthesis of squalene and cholesterol are discussed.

We wish to thank Professor A. Wormall for his generous gift of squalene and Dr R. K. Callow for infrared spectroscopy of the squalene. Miss Mary O'Donnell provided skilful technical assistance.

\section{REFERENCES}

Beinert, H. (1953). J. biol. Chem. 205, 575.

Bloch, K. (1953). Helv. chim. acta, 36, 1611.

Bloch, K. (1954). In: International Conference on Biochemical Problems of Lipids, Brussels, 11-13 June 1953, p. 281. Koninklijke Vlaamse Academie voor Wetenschappen, Letteren en Schone Kunsten van België.

Bonner, J. \& Arreguin, B. (1949). Arch. Biochem. Biophys. 109, 21.

Boyd, G. S. (1953). Biochem. J. 55, 892.

Brady, R. O. \& Gurin, S. (1951). J. biol. Chem. 189, 371.

Bucher, N. (1953). J. Amer. chem. Soc. 75, 498.

Calvin, M., Heidelberger, C., Reid, J. C., Tolbert, B. M. \& Yankwich, P. E. (1949). Isotopic Carbon, p. 255. New York: Wiley.

Cornforth, J. W., Hunter, G. D. \& Popják, G. (1953a). Biochem. J. 54, 590.

Cornforth, J. W., Hunter, G. D. \& Popják, G. (1953b). Biochem. J. 54, 597.

Curtius, T. (1895). J. prakt. Chem. 52, 222.

Fischer, E. \& Groh, R. (1911). Liebigs Ann. 383, 364.

Heilbron, I. M., Owens, W. M. \& Simpson, I. A. (1929). J. chem. Soc. p. 1630.

Klein, H. P. \& Lipmann, F. (1953a). J. biol. Chem. 203, 95. Klein, H. P. \& Lipmann, F. (1953b). J. biol. Chem. 203, 101. Klyne, W. (1954). Chem. \& Ind. p. 725.

Langdon, R. G. \& Bloch, K. (1953a). J.biol. Chem. 200, 129. Langdon, R. G. \& Bloch, K. (1953b). J. biol. Chem. 200, 135. Lynen, F., Reichert, E. \& Rueff, L. (1951). Liebigs Ann. 574, 1.

Lynen, F., Wessely, L., Wieland, O. \& Rueff, L. (1952). Angew. Chem. 64, 687.

Ogston, A. G. (1948). Nature, Lond., 162, 963.

Popják, G. (1950). Biochem. J. 46, 560.

Popják, G. (1954). Arch. Biochem. Biophys. 48, 102.

Popják, G., French, T. H., Hunter, G. D. \& Martin, A. J. P. (1951). Biochem. J. 48, 612.

Schwenk, E., Todd, D. \& Fish, C. A. (1954). Arch. Biochem. Biophys. 49, 187.

Stern, J. R., Coon, M. J. \& del Campillo, A. (1953). J. Amer. chem. Soc. 75, 1517.

Strain, H. H. (1933). J. biol. Chem. 102, 151.

Woodward, R. B. \& Bloch, K. (1953). J. Amer. chem. Soc. 75, 2023.

Wüersch, J., Huang, R. L. \& Bloch, K. (1952). J. biol. Chem. $195,439$. 